\title{
New Media from Plant Extracts for Isolation of Some Pathogenic Bacteria that Produce Protease on Linum Usitatissium Seed Powder Agar and to Identify Serratia Marcescens
}

\author{
Manal Khalid Mohammad ${ }^{1}$, Suhad Y. Abed ${ }^{1}$, Afrah Abdulridha Ajeel $^{1}$ \\ ${ }^{1}$ Researcher, M.Sc. of Microbiolgy, Collage of science, Department of Biology, Mustansiriyah University, Iraq
}

\begin{abstract}
Prepared two concentration of four new enriched media for isolation of some pathogenic bacteria including Acinetobacter baumannii, Klebsiella pneumoniae, Escherichia coli, and Serratia marcescens and identification of Serratiamarcescens that produce red pigment (prodigiosin). The first concentration $12.5 \mathrm{~g} / 1$ of plant extracte showed heavy growth of pathogenic bacteria on the four media. The second concentration $25 \mathrm{~g} / \mathrm{l}$ showed also growth of the pathogenic bacteria incubation in $37^{\circ} \mathrm{C}$ for $24 \mathrm{~h}$ except on the Elettaria cardemomum agar and, Fenugreek (Trigonella foenum-graecum) seeds agar. Serratia marcescens produce red pigment on all the new media in both concentration . All isolates produce protease enzyme on Linum usitatissium seed agar. The result is a synthesis enrichment and inexpensive medium for different species of bacteria like Linumusitatissium enriched with a different materials and salt as amineral that suitable for growth organism without any morphological change of metabolisms feature, also identification Serratia marcescens by produce red pigment that important in medical with a wide range of biological activities.
\end{abstract}

Keywords: Prodigiosin, Trigonella foenum-graecum, Serratia marcescens, pigment.

\section{Introduction}

Pathogenic bacteria causes different disease including pneumonia, tuberculosis, and food borne illnesses in immunocompromised patients and healthy individuals that have antibiotics resistance with wide range. ${ }^{(1)}$

Serratia marcescens is agram negative bacteria that secreted serratiopeptidase enzyme used for treatment sinusitis, surgery, arithritis and different disease ${ }^{(2,3,4,)}$. Prodigiosin is the red pigment secreted from Serratia marcescens with biological activities in wide range as anti fungal, immunosuppressant, antimalarial and antibiotic agent which produce the pigment needs optimum condition $^{(5,6)}$ including the presence of $\mathrm{NaCl}$, soy bean meal, $\mathrm{PH}$, temperature, salts, and others ${ }^{(7)}$.

Protease enzyme is one of an important indusatrial enzyme that produce from different type of pathogenic bacteria and use in medical, food, and industrial field. The Protease enzyme is an extracellular enzyme which responsible for virulence of pathogenic bacteria ${ }^{(8)}$.
The parts of plant consist of many different components that including proteins and oil some of which are carbohydrates, vitamins, sugar, aminoacids and minerals ${ }^{(9)}$. The plants can be found in many places and used for various diseases as therapeutic agent because the presence of phenol like tannins that have ability to form hydrogen bonds with carbohydrates and proteins by inhibition of some enzymes in the living cell leading to inhibit growth pathogenic bacteria ${ }^{(10,11)}$.

Elettaria cardamomum is one of spices old very in the world and commonly known as green or true cardamom, Heilin $\operatorname{Arabic}^{(12,13,14)}$.

This grain be smell and taste that containoils fixed and evolution in seeds and contains metal and material natural. Elettaria cardamomum have activity compounds are Glycosides, Saponins, Alkaloids, Volatile, and Tannins, Oils ${ }^{(15)}$.

Flax (Linum usitatissimum), also known as linseed or common flax ${ }^{(16)}$. 
Activity compounds of flaxseed (Linum usitatissimum) are saponins, flavonoids, Resins, glycosides, alkaloids, Vitamin, carbohydrates, Protein oil and oil components from fatty acids are fatty $\operatorname{acids}^{(17,18)}$.

Flaxseeds protecting from cancers, which contain high levels of fatty acids, and omega- 3 which inhibit the growth of cancerous tumors ${ }^{(19)}$.

Fenugreek (Trigonella foenum-graecum) is one of the medicinal plants

Common name is Fenugreek (Hilba), Scientific name: Trigonella foenum-graecum $L^{(20,21) \text {. }}$

The composition of Fenugreek seeinclude, alkaloids, coumarins, flavonoids, saponins and vitamins ${ }^{(22)}$.

Fenugreek seeds used in the treatment of stomach ulcer, and Urinary tract infection ${ }^{(23)}$.

Laurus nobilis $L$. from the family Lauraceae, thatcomprises numerous aromatic and medicinal plants $^{(24)}$.

The plant content of the compounds was identified effective by preliminary chemical tests of plant powder, plant leaves where the containment of tannins, saponins, flavonoids, alkaloids, glycosides, Resins, and Phenols. Antibacterial and antimicrobial propertiesare essential oil of leaves ${ }^{(25,26)}$.

\section{Materials and Method}

Sample of plant: The plant used in this study consisted of Laurus nobilis L. (bay laurel) leaf and, Flax (Linum usitatissimum) seeds, Elettaria cardamomum, Fenugreek (Trigonella foenum-graecum) seeds were purchased from a local market in Baghdad, Iraq and grounded to powder for further use.

Plant Extract Preparation: Aqueous hot extract: Weight $50 \mathrm{~g}$ of air-dried powder of plant was added to $500 \mathrm{ml}$ of distilled water, boiled for 15 minutes leave to cool then it was filtered through 6 layers of muslin cloth into a sterile flasklater the filtered plant extracts into sterile glass plate which dried in anoven for $24 \mathrm{~h}$. At 50 Celsius then crushed drying the plants extract into powder then preservation the drying particle into a sterile container for each plants extracts ${ }^{(27,28)}$.

Preparation plant powder agar: The (20g/l)agar-agar was Prepared (Difco) and autoclave at $121 \mathrm{C}^{0}$ for $15 \mathrm{~min}$ and cool to $(45-55)^{\circ} \mathrm{C}$ then added plants powder $(25 \mathrm{~g} / \mathrm{l})$ the $\mathrm{pH}$ was adjusted to 7.0 mixed well and dispensed into sterile Petri dishes for each type of plants ${ }^{(29)}$. Another concentration $12.5 \mathrm{~g} / \mathrm{l}$ will prepared at the same method. The media (Linum usitatissimum seeds agar, Laurus nobilis L. leaves agar, Trigonella foenum-graecum seeds agar and Elettaria cardamomum agar) were inoculated with isolates of (Acinetobacter baumannii, Klebsiella pneumoniae, Escherichia coli, and Serratiamarcescens) and incubated at $37^{\circ} \mathrm{C}$ for 24 hours.

Microbial isolates: Four isolates Acinetobacter baumannii, Klebsiellapneumonia, Serratia marcescens, and Escherichia coli were isolated from clinical specimens that had been submitted to the bacteriology laboratory in Al-Kindy Educational Hospital, Baghdad, Iraq. The Vitek 2 system (Biomerieux) using to identified all isolates.

\section{Results and Discussion}

All isolates showed a growth onLinum usitatissimum agar, Laurus nobilis L. agar and Trigonella foenumgraecum agar and Elettaria cardamomum agar that prepared in the first concentration $12.5 \mathrm{~g} / \mathrm{l}$ all isolate incubated in $37 \mathrm{C}^{0}$ for 24 hours as shown in (fig.1, 2) (Table 1 ), while the second concentration $25 \mathrm{~g} / 1$ shown also growth of pathogenic bacteria on Linum usitatissimum agarand Laurus nobilis L. agarexcept Elettaria cardamomum agarand Trigonella foenum-graecum agar no pathogenic bacteria growth (Fig.3)(Table2). These four new media contain many compounds like proteins, carbon, vitamins, minerals, salts, fatty acids, oils, and other nutrition factors ${ }^{(48)}$. While Elettaria cardamomum contain the some nutrition factor, is useful as good media for growth in low concentration but in high concentration cause kill of bacteria because contain antimicrobial agent for various disease moreover due to the presence of phenolic compounds, alkaloid, glycosides, saponins, tannins and other compound ${ }^{(4)}$. Serattia marcescens produce red pigment in all new four media but on Laurus noilis L. agar cannot mentioned this pigment in the first concentration 12.5g/l (fig.1, 2, 3, 4) (Table 1, 2). That a useful media for to rapid identified and enumerated Serratia marcescens because this medium contain the main compound and condition to produce the red pigment, $\mathrm{PH}$, temperature, source of carbon, nitrogen and salt ${ }^{(29,30,26,27)}$. All pathogenic bacteria Hydrolysis a protein is very clear in Linum usitatissimum agar that by produce protease enzyme because the media contain $18 \mathrm{~g}$ protein/100g linum (fig.4) ${ }^{(48)}$. 
Table (1) : Growth of pathogenic bacteria on plant extracts in $12.5 \mathrm{~g} / \mathrm{l}$ of concentration incubated in $37 \mathrm{C}$ for 24 hours.

\begin{tabular}{|l|c|c|c|c|}
\hline \multirow{2}{*}{ Sample of plant } & \multicolumn{4}{|c|}{ Pathogenic bacteria } \\
\cline { 2 - 5 } & $\begin{array}{c}\text { Acinetobacter } \\
\text { baumannii }\end{array}$ & $\begin{array}{c}\text { Serratia } \\
\text { marcescens }\end{array}$ & $\begin{array}{c}\text { Klebsiella } \\
\text { pneumoniae }\end{array}$ & Escherichia coli \\
\hline Linum usitatissimum seed agar & + & + & + & + \\
\hline Laurus noilis L. agar & + & ++ & + & + \\
\hline Fenugreek (Trigonella foenum- araecum) seed agar & ++ &,$++ \mathrm{P}$ & ++ & ++ \\
\hline Eletaria cardamomum agar & ++ &,$++ \mathrm{P}$ & ++ & ++ \\
\hline
\end{tabular}

$\mathrm{P}$ : produce of red pigment; ++ : Heavy growth of pathogenic bacteria; + : growth of pathogenic bacteria; $\_$: No growth

Table 2: Growth of pathogenic bacteria on plant extracts in $25 \mathrm{~g} / \mathrm{l}$ of concentration incubated in $37 \mathrm{C}$ for 24 hours.

\begin{tabular}{|l|c|c|c|c|}
\hline \multirow{2}{*}{ Sample of plant } & \multicolumn{4}{|c|}{ Pathogenic bacteria } \\
\cline { 2 - 5 } & $\begin{array}{c}\text { Acinetobacter } \\
\text { baumannii }\end{array}$ & $\begin{array}{c}\text { Serratia } \\
\text { marcescens }\end{array}$ & $\begin{array}{c}\text { Klebsiella } \\
\text { pneumoniae }\end{array}$ & Escherichia coli \\
\hline Linum usitatissium seed agar & ++ &,$++ \mathrm{P}$ & ++ & ++ \\
\hline Laurus nobilis L. leaves agar & + &,$+ \mathrm{P}$ & + & + \\
\hline Fenugreek (Trigonella foenum-graecum) seed agar & - & - & - & - \\
\hline Elettaria cardemomum agar & - & - & - & - \\
\hline
\end{tabular}

$\mathrm{P}:$ produce of red pigment; ++ : Heavy growth of pathogenic bacteria; + : growth of pathogenic bacteria; $\_$: No growth

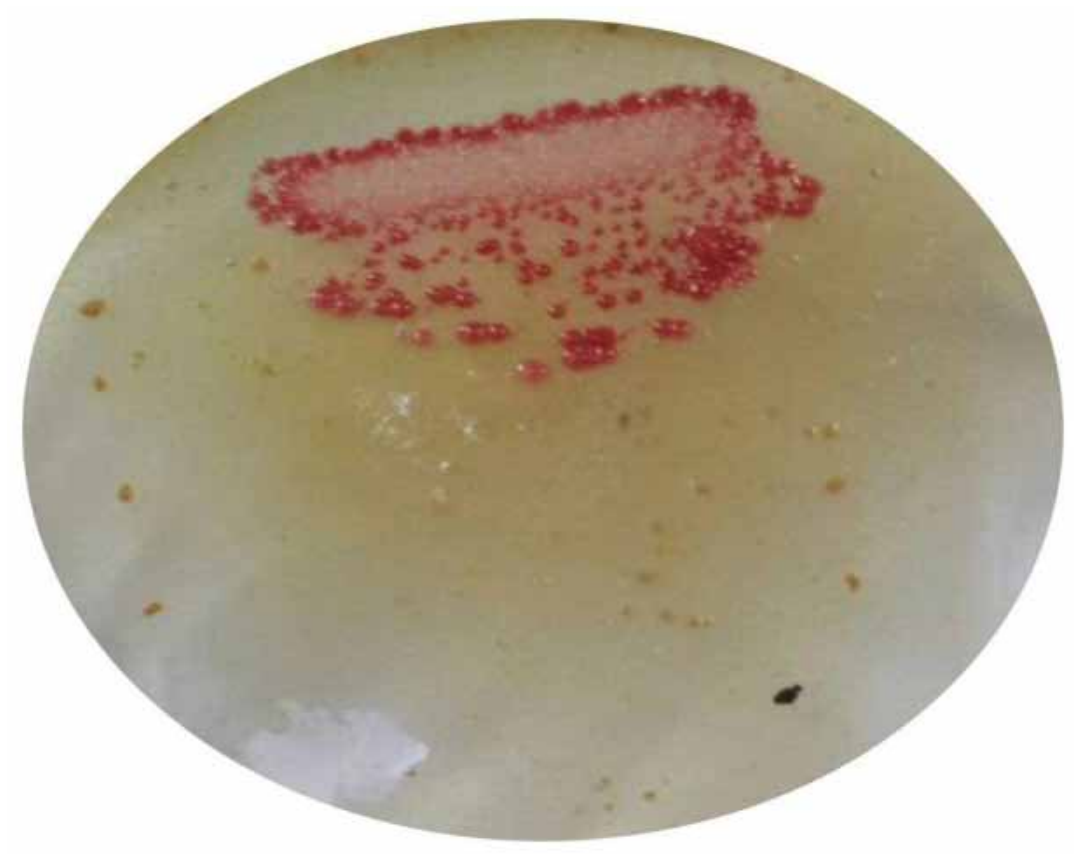

Figure 1: Shown growth and red pigment of Serratia marcescens on Linum usitatissium seeds agar at 12.5g/l concentration incubated in $37^{\circ} \mathrm{C}$ at 24 hours. 


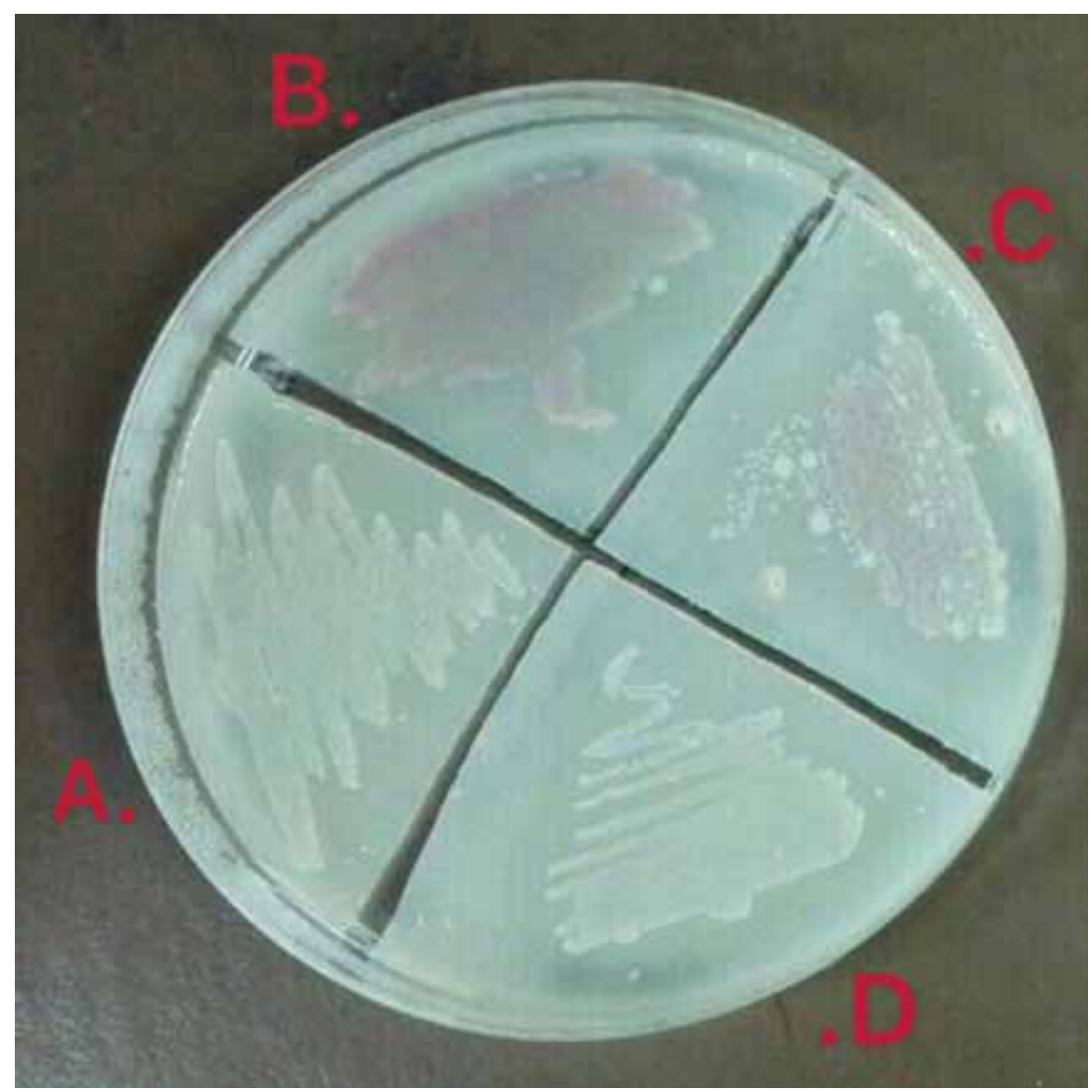

Figure 2: Pathogenic bacteria shown heavy growth on Laurus nobilis L.leaves agar at $12.5 \mathrm{~g} / \mathrm{l}$ concentration incubated in $37 \mathrm{C}^{0}$ at 24 hours, A. Acinetobacter baumannii, B. Serratia marcescens, C. Klebsiella pneumoniae, and D. Escherichia coli

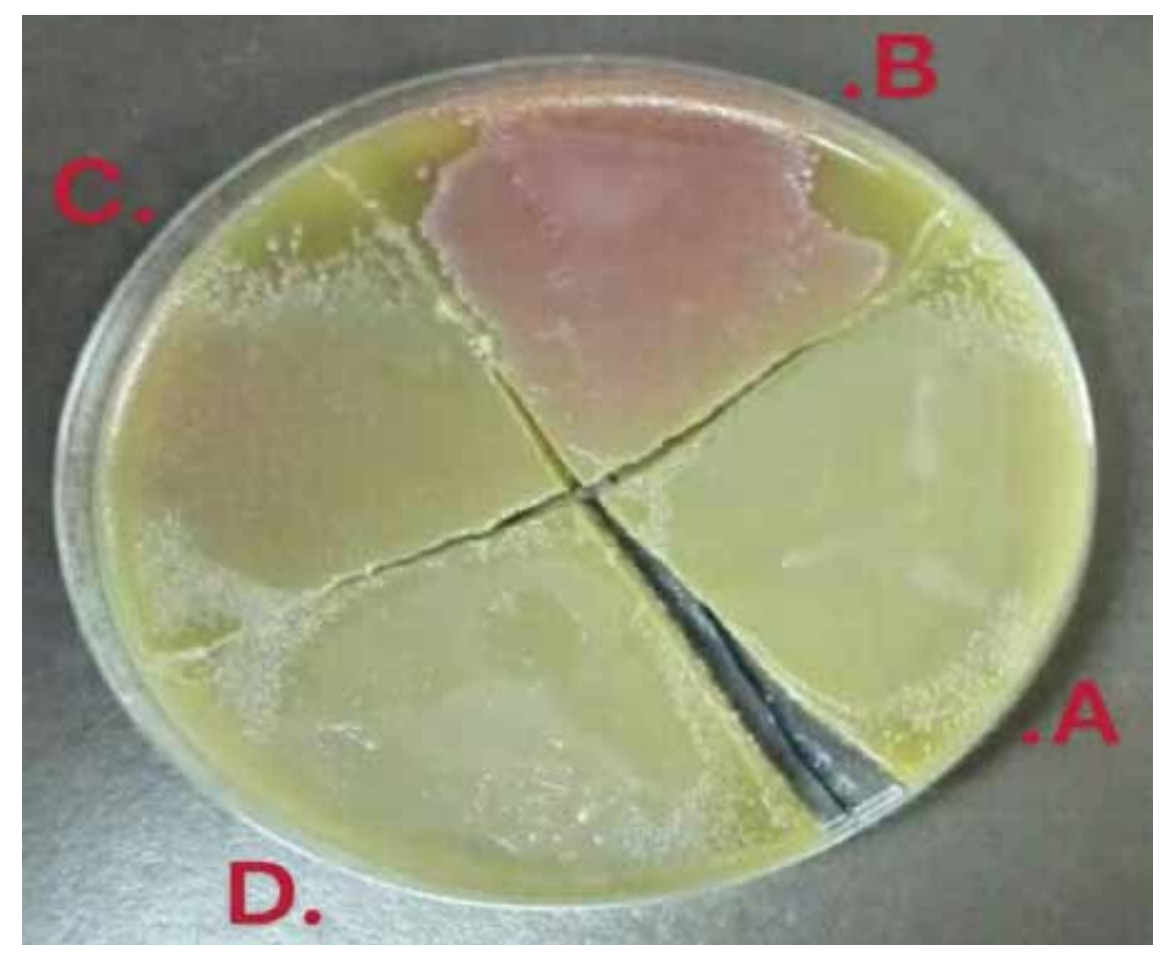

Figure 3: Pathogenic bacteria growth on Laurus nobilis L.leaves at $25 \mathrm{~g} / \mathrm{l}$ concentration incubated in $37 \mathrm{C}^{0}$ at 24 hours, A. Acinetobacter baumannii, B. Serratia marcescens, C. Klebsiella pneumoniae, and D. Escherichia coli. 


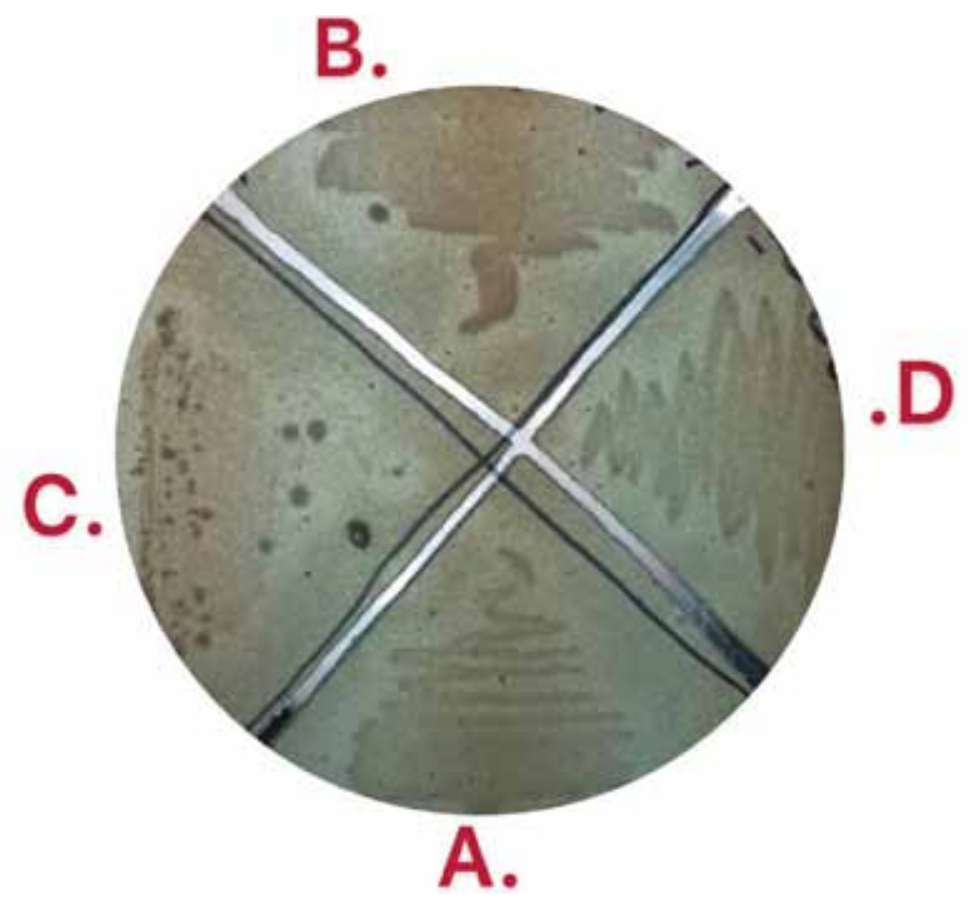

Figure 4: All Pathogenic bacteria growth shown Hydrolysis a protein clear zone on Linum usitatissium seeds agar at 25g/l concentration incubated in $37 \mathrm{C}^{0}$ at 24 hours, A. Acinetobacter baumannii, B. Serratia marcescens, C. Klebsiella pneumoniae, and D. Escherichia coli.

Ethical Clearance: The Research Ethical Committee at scientific research by ethical approval of both $\mathrm{MOH}$ and MOHSER in Iraq.

\section{Conflict of Interest: Non}

Funding: Self-funding

\section{References}

1. Manal, K. Production, partially purification and estimationofserratiopeptidase from Serratia marcescens: Al-Mustansiriyah Journal of Science 2016;27: 33-35.

2. Manal, K .M. .Effect of temperature and mutation onserratiopeptidase secreted from Serratia marcescens: J. of Geneticand Environment Resources Conservation. 2015;3:35-37.

3. Chaudhari,A;Mali,K.:Production characteristicand optimization of potent protease (serratiopeptidase) from Serratia marcescens E15. Int. Res. J. Pharm. App. Sci. 2013;3(4):95-98.

4. Salih, A. Optimal condition measured for production ofprodigiocin from Environmental research center Serratia marcescensbacteria isolated from different source 2016;(3):116-128.
5. Schlegel, Hanc G., Generalmicrobiology (7ed). Cambridge Univ. Press. 1995; pp. 204-205.

6. "Serratia". University of Texas at Houston Medical School. Archived from the original on 2007-01-28. Retrieved 2007-03-14.1. Elettaria cardamomumKöhler-s Medizinal-Pflanzen - Franz Eugen Köhler, Köhler's Medizinal-Pflanzen

7. Tenaillon O, Skurnik D, Picard B, Denamur E (March 2010). "The population genetics of commensal Escherichia coli". Nature Reviews. Microbiology. 8 (3): 207- doi:10.1038/ nrmicro2298. PMID 20157339.

8. Handric, L.W. Production of beta-glucan-mannan preparation by autolysis of cell under certain $\mathrm{pH}$, temperature and time condition united state patent No. 2002; 644(12): 211-218.

9. Elettaria cardamomum -Kohler-s MedizinalPflanzen-Franz Eugen Kohler, Kohler MedizinalPflanzen

10. "Kew World Checklist of Selected Plant Families". Apps.kew.org. Retrieved 2018-05 29.

11. Larsen, K. A prelimanary checklist of the Zingiberaceae of Thailand. Thai Forest Bulletin (Botany)1996; 24: 35-49. 
12. Antimicrobial activities of solanum incanum, elettaria cardamomum, and zingiber officinale used traditionally to treat pathogenic microbes; e.a. ewais; magdam. aly; m.a. ismail; e.h. abdel shakour and m.f. hassanin 2014.

13. P.N. Ravindran M. Divakaran G.S. Pillai, Handbook of Herbs and Spices (Second edition), Volume 2, 2012, 27.9.1 Medicinal uses

14. "Linum usitatissimum". Germplasm Resources Information Network (GRIN). Agricultural Research Service (ARS), United States Department of Agriculture (USDA). Retrieved 2 October 2014.

15. Cheeseman MA (24 August 2009). "GRAS Petition by Flax Canada, Agency Response Letter GRAS Notice No. GRN 000280". U.S. Food and Drug Administration. Archived from the original on 17 June 2015. Retrieved 1 June 2015.

16. Pan, An; Yu, Danxia; Demark-Wahnefried, Wendy; Franco, Oscar H.; Lin, Xu . "Meta-analysis of the effects of flaxseed interventions on blood lipids". The American Journal of Clinical Nutrition.2009; 90 (2): 288-297.

17. "10 Flax Seed Benefits and Nutrition Facts", Dr .Axe.

18. Dietary Induced Sporadic Colon Cancer (2009), Leonard H Augenlicht

19. Ouzir, M; El Bairi, K; Amzazi, S ."Toxicological properties of fenugreek (Trigonella foenum graecum)". Food and Chemical Toxicology.2016; 96: 145-54.

20. Saunders, W. B. (1998). Trease and Evan's pharmacognosy. Typeset by Technical Typesetters, Ashford, Kent, UK.
21. Barners D, Anderson LA, Phillipson JD.Herbal Medicines: A guide for health care professionals, 2nd ed., pharmaceutical press. London. 2002.

22. "Hilba (Fenugreek paste) Cooking with chilies recipe". Cookipedia.co.uk. Retrieved

23. Stace, C. A. New Flora of the British Isles (Third ed.). Cambridge, U.K.: Cambridge University Press. 2010.

24. Brown, R.W. Composition of scientific words: A manual of method and a lexicon of materials for the practice of logotechnics. Washington, D.C.: Smithsonian Institution Press. 1956.

25. Knobloch, K., A. Pauli, N. Iberl, N. Weigand and H.M Weis: Antibacterial andantifungal properties of essential oil components. J. Ess. Oil Res., 1989; $1,119-128$

26. Ozcan, M. and O. Erkmen: Antimicrobial activity of the essential oils of Turkishplant spices. Eur. Food Res. Technol. 2001; 212, 658-660

27. Parekh, J. and Chanda, S. Screening of Aqueous and Alcoholic Extracts of Some Indian Medicinal Plants for Antibacterial Activity. Indian Journal of Pharmaceutical Sciences. 2006; 68, 835-838.

28. AL-abid, M.R. 1985. Aurzu sammen strungder Abschla B membrane in phenix dactilyfra. Wurzhurg University.

29. Hamzia, A.A. Two new media apple leaves agar and eggplantleaves agar for identification of Creptococcus newformance: J. of Biology Agricultural and Healthcare. 2014; 4:126-131. 